AGRICULTURE AND BIOLOGY JOURNAL OF NORTH AMERICA

ISSN Print: 2151-7517, ISSN Online: 2151-7525, doi:10.5251/abjna.2012.3.8.326.331

(C) 2012, ScienceHuß, http://www.scihub.org/ABJNA

\title{
Potentials of some cement by-products for liming of an acid soil in the humid zone of South-Western Cameroon
}

\author{
Emilia B. Ngane ${ }^{1}$, Aaron S. Tening ${ }^{\star 2}$, Eugene E. Ehabe ${ }^{1}$ and Frederic Tchuenteu ${ }^{1}$ \\ ${ }^{1}$ Institute of Agricultural Research for Development (IRAD), Ekona Regional Centre, PMB 25 \\ Buea, Cameroon. \\ ${ }^{2}$ Department of Chemistry, University of Buea, P.O. Box 63, Buea, Cameroon \\ ${ }^{*}$ Corresponding author: Tel.: +237 77753400 \\ E-mail: suhtening@yahoo.com
}

\begin{abstract}
Aluminium (Al) toxicity is the major limiting factor of plant growth in acid soils. A pot trial was carried out to evaluate the effects of lime $\left(\mathrm{CaCO}_{3}\right)$ from three liming materials on soil Al toxicity and the yield of maize (Zea mays L.). Two cement by-products (Agri-56 and Filler) and a conventional liming material (Limbux) were used. The acid neutralizing values for Limbux, Agri-56 and Filler were 126, 88 and $34 \% \mathrm{CaCO}_{3}$ equivalent, respectively. Five rates of lime equivalent: 0 , 2, 4, 8 and 16 tons $\mathrm{CaCO}_{3}$ ha $^{-1}$ and the three liming materials were applied in combinations as treatments. Agri-56 was as efficient as Limbux in neutralizing Al toxicity. Aluminium saturation decreased from $83 \%$ to 31,37 and $69 \%$ for Limbux, Agri-56 and Filler, respectively when 2 tons $\mathrm{CaCO}_{3}$ ha $^{-1}$ was applied. Limbux and Agri-56 increased the soil pH from 4.3 to 7.1 and 6.5, respectively at equivalent rate of 16 tons $\mathrm{CaCO}_{3}$ ha $^{-1}$. There was a 53.5 and $67.2 \%$ increase in maize yield for Limbux and Agri-56, respectively when 2 tons $\mathrm{CaCO}_{3} \mathrm{ha}^{-1}$ was applied. Because of its availability and easy to use, Agri-56 is therefore recommended as the liming material on the acid soils of South-western Cameroon.
\end{abstract}

Key words: Acid soil, aluminium toxicity, cement by-products, liming material, Zea mays L.

\section{INTRODUCTION}

Acid soils are widespread in Cameroon and cover about $75 \%$ of agricultural lands in the country (Sieffermann, 1973). Acid soils are generally highly weathered, but very different in their mineralogical, physical and chemical properties (Keng and Uehara, 1974). Soil acidity is common in all regions where precipitation is high enough to leach appreciable amounts of exchangeable bases from the surface of the soil. Acid soils are prevalent in areas experiencing high annual rainfall of about $1500 \mathrm{~mm}$ or more (Conyers, 1986). These soils, especially the ultisols and oxisols usually have problems associated with Al toxicity, low nutrient status, nutrient imbalance and multiple nutrient deficiencies (Sanchez, 1987; Adiloğlu and Adiloğlu, 2004). Under pH 4 or less, most macronutrients become limited to the plant and a toxic form of $\mathrm{Al}\left(\mathrm{Al}^{3+}\right)$ increases its availability and can be a major limiting factor of plant growth and production in acid soils (Kochian, 1995; Matsumoto, 2000). Causes of soil acidity have been attributed to inorganic fertilizer application and biological nitrogen fixation (Bolan et al., 1991) and acid rain (Raij, 1991).

Conventional lime still remains the major means of ameliorating soil acidity but must farmers still find it difficult to purchase it coupled with the subsoil acidity associated with inadequate liming practice. Agricultural liming has increased with agricultural intensification and periodic use has become necessary to counteract acidification of cultivated soils (Helyar and Porter, 1989; Fisher et al., 2003). The benefits of liming include increased soil $\mathrm{pH}$, calcium and magnesium saturation, neutralisation of toxic concentrations of $\mathrm{Al}$, increase in phosphorus, improved nutrient uptake by plants and increased crop yield (Nicholaides et al., 1983; Oguntoyinbo et al., 1996; Oluwayinbo et al., 2005; Anetor and Akinrinde, 2006). Agricultural lime refers to all limestone-derived materials used to neutralize acid soils, including ground limestone (calcium carbonate$\mathrm{CaCO}_{3}$ ), hydrated lime (calcium hydroxide- $\mathrm{Ca}(\mathrm{OH})_{2}$ ), or burned lime (calcium oxide-CaO), with or without additions of magnesium carbonate $\left(\mathrm{MgCO}_{3}\right)$, 
magnesium hydroxide $\left(\mathrm{Mg}(\mathrm{OH})_{2}\right)$, or magnesium oxide $(\mathrm{MgO})$.

To attenuate the negative impacts of the factors that are associated with acid infertility, it is usually recommended to apply liming materials to the soil, and thus boost agricultural yields. The objective of this study was to evaluate the liming effects of some cement by-products on acid soil infertility factors and agricultural production.

\section{MATERIALS AND METHODS}

The study site is the Missellele series, near Tiko, in the South-western region of Cameroon. It is a major acid soil of the much extended yellow old coastal marine deposits of the Atlantic Ocean. This soil is classified as a Typic Paleustult (Soil Survey Staff, 1994). The field is located at latitude $4^{\circ} 30^{\prime} \mathrm{N}$ and longitude $9^{\circ} 20^{\prime} \mathrm{E}$, and at 55 metres above mean sea level. The mean monthly temperatures and relative humidity of the area are relatively constant throughout the year $\left(25-30^{\circ} \mathrm{C}\right.$ and $78-88 \%$, respectively) with distinct rainfall patterns and number of isolation hours (Le Roux et al, 2000). The area has a bimodal rainfall pattern with a major rainy and cloudy season from July to October and a dry and sunny season from December to February/March. Large agro-industrial plantations (Cameroon Development Corporation (CDC) and Del Monte) with banana, oil palm and rubber as the major tree crops are established on this soil. Only a very small percentage of the land is exploited by the peasant farmers.

Representative topsoil samples $(0-20 \mathrm{~cm})$ were collected, air-dried, ground and sieved to pass through a 2-mm sieve. They were analyzed in the laboratory for their physicochemical properties using conventional analytical methods (Black et al., 1965; Tchuenteu and Schalk, 1988).

Two cement by-products from a local cement producing company (Cimenteries du CamerounCIMENCAM) in Douala and a well known agricultural lime (Limbux), imported from the United States of America were selected for the study. The cement by-products were designated "Agri-56" from Figuil cement factory in the North Region of Cameroon, and "Filler" from Bonaberi cement factory in the Littoral Region of Cameroon. The original material of Filler is a volcanic ash from the volcanic zones of southwestern Cameroon, while that of Agri-56 is a calcareous rock.
The three lime materials were analyzed for their chemical composition. Total elemental analysis by wet acid digestion procedure allowed for the determination of sodium ( $\mathrm{Na})$, potassium $(\mathrm{K})$, calcium (Ca) and magnesium (Mg) oxide contents, and subsequently their acid neutralizing values, in terms of calcium carbonate equivalent (FAO-UNDP, 1979)

A pot trial was carried out in the greenhouse to evaluate the effect of liming materials (Table 1) on the yield of maize (Zea mays L.). The experiment had three liming materials (Limbux, Agri-56 and Filler), which were used at the equivalent rates of $0,2,4,8$ and 16 tons per hectare in terms of $\mathrm{CaCO}_{3}$ equivalent. The treatments were replicated three times in a completely randomized design (CRD). In order to insure maximum yield, baseline fertilization, made of 200, 100, 100 and $50 \mathrm{mg} \mathrm{kg}^{-1} \mathrm{~N}, \mathrm{P}, \mathrm{K}$ and $\mathrm{Mg}$, respectively, was applied to all the pots in the form of urea, triple superphosphate, muriate of potash and kieserite, respectively.

Table 1. Rates of lime equivalent to calcium carbonate and liming materials.

\begin{tabular}{|l|l|l|l|}
\hline $\begin{array}{l}\text { Lime } \\
\text { Equivalent }\end{array}$ & Limbux & Agri-56 & Filler \\
\hline \multicolumn{4}{|c|}{ ton ha ${ }^{-1}-$} \\
\hline 0 & 0 & 0 & 0 \\
\hline 2 & 1.6 & 2.4 & 6 \\
\hline 4 & 3.2 & 4.8 & 12 \\
\hline 8 & 6.4 & 9.6 & 24 \\
\hline 16 & 12.6 & 19.2 & 48 \\
\hline 1 & & & \\
\hline
\end{tabular}

The fertilizers and liming materials were intimately mixed with $2,500 \mathrm{~g}$ of soil. Five seeds of maize (Zea mays L.) were sown in each pot, and thinned to three plants per pot one week after planting. Field moisture capacity was maintained throughout the 28 days growing period. Plant tops were then harvested, washed in distilled water, dried in ventilated oven at $70^{\circ} \mathrm{C}$, weighed for dry matter yield. Maize yields were thus estimated as dry matter weight per pot. Soils in pots were sampled, air-dried and processed for the analysis of liming effects on soil properties and productivity. The results were analysed using SPSS version 11.0 for Windows to establish the relationships between liming rates, the soil parameters and maize yield.

\section{RESULTS AND DISCUSSION}

Chemical and physical properties of the acid soil used in the study: The physicochemical properties 
of the soil used in the study are presented in Table 2. This soil was strongly acidic, with a $\mathrm{pH}$ value of 4.5 and an $\mathrm{Al}$ saturation of $73 \%$. Essential nutrient elements were low in the soil. Nitrogen had a value of $0.09 \%$, available phosphorus was $12 \mathrm{mg} \mathrm{kg}^{-1}$ and exchangeable bases had values of $0.02,0.73$ and
$0.03 \mathrm{cmol} \mathrm{kg}^{-1}$ for $\mathrm{K}, \mathrm{Ca}$ and $\mathrm{Mg}$, respectively. These values are in line with those determined by Tening et al. (2008). The soil was therefore in desperate need of liming. The $\mathrm{C} / \mathrm{N}$ ratio of 12.9 indicates that the soil is rich in humus (Foth, 1984).

Table 2: Physicochemical properties of the acid soil used in the study.

\begin{tabular}{|c|c|c|c|c|c|c|c|c|c|c|c|c|c|c|}
\hline \multirow[t]{2}{*}{ Sand } & \multirow[t]{2}{*}{ Silt } & \multirow[t]{2}{*}{ Clay } & \multirow{2}{*}{$\begin{array}{l}\text { Text. } \\
\text { class }\end{array}$} & \multirow{2}{*}{$\begin{array}{l}\text { Org. } \\
\text { C }\end{array}$} & \multirow{2}{*}{$\begin{array}{l}\text { Total } \\
\mathrm{N}\end{array}$} & \multirow[t]{2}{*}{$\mathrm{C} / \mathrm{N}$} & \multirow{2}{*}{$\begin{array}{l}\mathrm{pH} \\
\left(\mathrm{H}_{2} \mathrm{O}\right)\end{array}$} & \multirow{2}{*}{$\begin{array}{l}\text { Avail } \\
\text { P }\end{array}$} & \multicolumn{4}{|c|}{ Exchangeable Cations } & \multirow[t]{2}{*}{ ECEC } & \multirow{2}{*}{$\begin{array}{l}\text { Al } \\
\text { Sat.* }\end{array}$} \\
\hline & & & & & & & & & $\mathrm{K}$ & $\mathrm{Ca}$ & $\mathrm{Mg}$ & $\mathrm{Al}$ & & \\
\hline 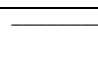 & $\%$ & & & -0 & & & & $\mathrm{mg}^{-1}$ & & & nol kc & & & $\%$ \\
\hline 43.9 & 11.8 & 44.3 & $\begin{array}{l}\text { Sandy } \\
\text { clay }\end{array}$ & 1.16 & 0.09 & 12.9 & 4.5 & 12 & 0.02 & 0.73 & 0.03 & 2.62 & 3.59 & 73 \\
\hline
\end{tabular}

${ }^{*}$ Exchangeable Al divided by the Effective Cation Exchange Capacity x 100 (Evans and Kamprath, 1970).

Chemical characteristics and acid neutralizing values of liming materials: The levels of acid $(\mathrm{pH})$ and basic character (total $\mathrm{Na}, \mathrm{K}, \mathrm{Ca}$ and $\mathrm{Mg}$ oxides) of the liming materials were determined and presented in Table 3 . These materials were very basic with $\mathrm{pH}$ values greater than 10 . There were high levels of $\mathrm{CaO}$ (69.4 and 46.1\%) in Limbux and Agri-56, respectively, but a very low level of $\mathrm{CaO}$ $(8.8 \%)$ in Filler. The calcium carbonate equivalents, corresponding to the acid neutralizing values, were 126, 88 and $34 \%$ for Limbux, Agri-56 and Filler, respectively.

Effects of liming materials on soil properties: The effects of liming on soil properties and maize yield are shown in Table 4 and Fig.1. Soil pH increased from 4.3 to 7.1 and 6.5 for Limbux and Agri-56, respectively, but only to 5.0 for Filler, at equivalent rate of 16 tons ha ${ }^{-1}$ calcium carbonate (Fig. 1a). The
$\mathrm{pH}$ response to liming of tropical acid soils has been extensively reviewed by several researchers (Pearson, 1975; Oluwatoyinbo et al., 2005; Anetor and Akinrinde, 2006). The rise in $\mathrm{pH}$ is important because it is going to enhance the availability of $P$. Oluwatoyinbo et al. (2005) demonstrated that liming had an effect on $\mathrm{P}$ uptake when initial $\mathrm{pH}$ was 5.8 .

Aluminium saturation decreased exponentially as liming levels increased (Fig. 1b). In Missellele soil, Al saturation decreased from $83 \%$ to 31,37 and $69 \%$ for Limbux, Agri-56 and Filler, respectively when 2 tons $\mathrm{ha}^{-1} \mathrm{CaCO}_{3}$ was applied. This was in line with Evans and Kamprath (1970) who showed that liming practically neutralized all Al toxicity induced by high levels of $\mathrm{Al}$ in soil solution and high Al saturation. While Limbux and Agri-56 showed some similarity in their neutralizing power, Filler was quite ineffective.

Table 3: Chemical composition and neutralizing values of liming materials used in the study.

\begin{tabular}{|l|l|l|l|l|l|l|l|}
\hline Liming material & $\mathbf{p H}$ & $\mathrm{Na}_{2} \mathbf{O}$ & $\mathbf{K}_{2} \mathbf{O}$ & $\mathbf{C a O}$ & MgO & $\begin{array}{l}\mathrm{CaCO}_{3} \\
\text { Equivalent }^{*}\end{array}$ \\
\hline & & & & & \\
\hline Limbux & 11.0 & $0.0(1.6)$ & $0.0(1.1)$ & $69.4(1.8)$ & $0.4(2.5)$ & 126 \\
\hline Agri-56 & 10.0 & $0.0(1.6)$ & $0.0(1.1)$ & $46.1(1.8)$ & $2.0(2.5)$ & 88 \\
\hline Filler & 10.3 & $0.2(1.6)$ & $0.1(1.1)$ & $8.8(1.8)$ & $7.1(2.5)$ & 34 \\
\hline
\end{tabular}

*Sum of the neutralising values of the various oxides [(\%Composition of oxide $A \times$ neutralising value of oxide $A)+$ (\%Composition of oxide $B \times$ neutralising value of oxide B) $+(\ldots \ldots .)$.$] (Foth, 1984)$

Values in parentheses are the neutralising values, calculated as molecular weight of $\mathrm{CaCO}_{3} / \mathrm{molecular}$ weight of corresponding oxides. 
Agric. Biol. J. N. Am., 2012, 3(8): 326-331

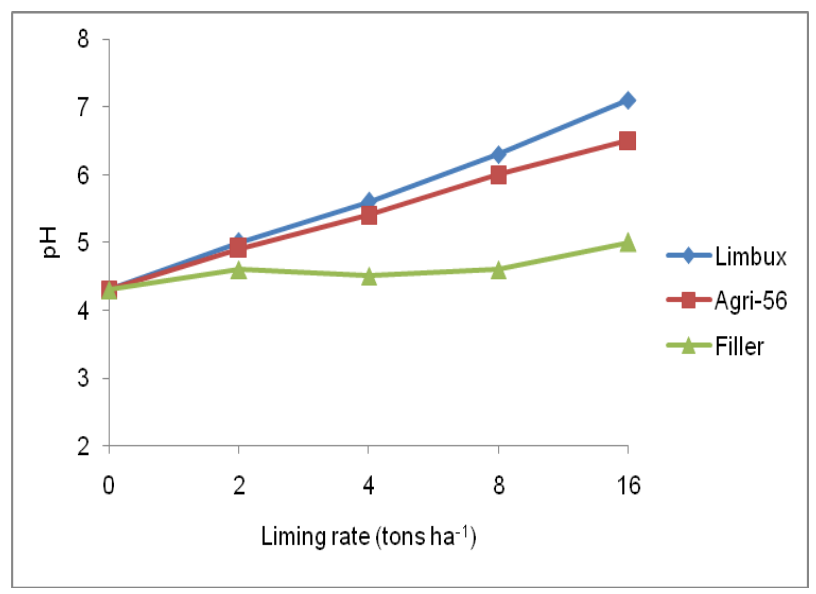

(a)

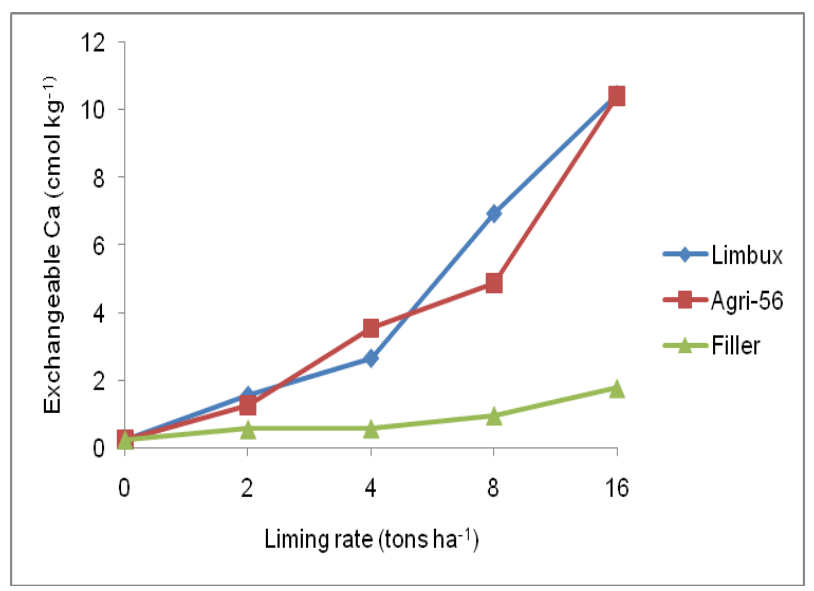

(c)



(b)

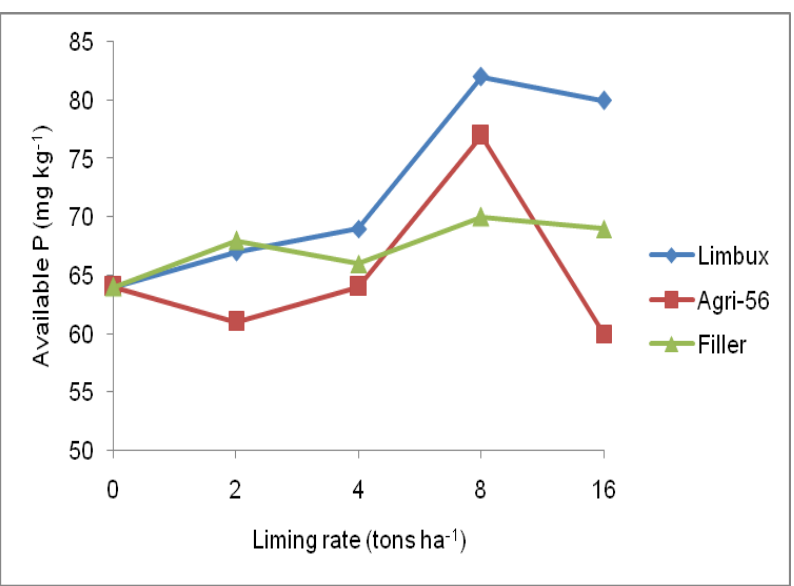

(d)



(e)

Fig 1. The effects of liming on (a), $\mathrm{pH}$ (b) Al saturation, (c) exchangeable $\mathrm{Ca}$, (d) available $\mathrm{P}$ and (e) dry matter yield of a typical acid soil in South-western Cameroon. 
Exchangeable $\mathrm{Ca}$ increased with liming treatments, and with all the liming sources (Fig. 1c). There was a significant $\left(p<0.01, r=0.727^{\star *}\right)$ relationship between liming rates and exchangeable $\mathrm{Ca}$. This was also reflected in the ECEC of the soil.

Bray-2 available $P$ was slightly improved with liming, up to a $\mathrm{pH}$ value of 8 , and then decreased (Fig. 1d). Oluwatoyinbo et al. (2005) found out that lime had significantly positive effect on $\mathrm{P}$ concentration in plant and actually reduced the amount of fertilizer $P$ required for optimum yield.

The effects of liming on crop yields: There was a 53.5 and $67.2 \%$ increase in maize yield when about 2 tons ha ${ }^{-1}$ of Limbux and Agri-56, respectively were applied (Table 4). The optimum yield corresponded to a $\mathrm{pH}$ of 4.9-5.0 and an Al saturation level of 31-
37\% (Table 4). Singh and Balasubramanian (1983) observed that lime effect was high only when $\mathrm{pH}$ was less than 5.0, and that the yield increase in acid low fertility soils lies in the use of well-balanced fertilization application, in addition to liming to alleviate acidity if any. Lime effect on yields was positive at low rates. While the decline in yield was observed after 2 tons ha $^{-1}$ of Limbux and Agri-56 were applied (Fig. 1e), the decline only started when 4 tons ha ${ }^{-1}$ of Filler was applied. This could be seen from the non significant $(p>0.05)$ negative relationship between liming rates and maize yield (Table 5). This trend was also observed by Oluwatoyinbo et al. (2005) who found out that the combination of the lowest rates of lime and $P$ was found to be optimum for plant growth.

Table 4: Effects of liming materials on soil properties and maize yield.

\begin{tabular}{|c|c|c|c|c|c|c|c|c|c|c|}
\hline $\begin{array}{l}\text { Liming } \\
\text { rate }\end{array}$ & $\begin{array}{l}\text { Liming } \\
\text { material }\end{array}$ & $\mathrm{pH}$ & $\begin{array}{l}\mathrm{Al} \\
\text { sat }\end{array}$ & Exch.K & $\begin{array}{l}\text { Exch. } \\
\mathrm{Ca}\end{array}$ & $\begin{array}{l}\text { Exch. } \\
\mathrm{Mg}\end{array}$ & ECEC & Total N & Avail. $\mathrm{P}$ & $\begin{array}{l}\text { Maize } \\
\text { yield }\end{array}$ \\
\hline Tons ha-1 & & & $(\%)$ & & $\mathrm{cmol} \mathrm{kg}^{-}$ & & & (\%) & $\left(\mathrm{mg} \mathrm{kg}^{-1}\right)$ & $\left(g_{p o t}^{-1}\right)$ \\
\hline 0 & - & 4.3 & 83 & 0.03 & 0.24 & 0.11 & 3.32 & 0.10 & 64 & 8.51 \\
\hline \multirow[t]{3}{*}{2} & Limbux & 5.0 & 31 & 0.03 & 1.56 & 0.11 & 2.33 & 0.10 & 67 & 13.06 \\
\hline & Agri-56 & 4.9 & 37 & 0.03 & 1.27 & 0.11 & 2.31 & 0.13 & 68 & 14.23 \\
\hline & Filler & 4.6 & 69 & 0.03 & 0.56 & 0.03 & 3.28 & 0.12 & 68 & 9.64 \\
\hline \multirow[t]{3}{*}{4} & Limbux & 5.6 & 3 & 0.03 & 2.66 & 0.00 & 2.89 & 0.10 & 69 & 12.64 \\
\hline & Agri-56 & 5.4 & 3 & 0.03 & 3.54 & 0.11 & 3.89 & 0.10 & 64 & 12.41 \\
\hline & Filler & 4.5 & 68 & 0.03 & 0.58 & 0.10 & 3.08 & 0.11 & 66 & 11.88 \\
\hline \multirow[t]{3}{*}{8} & Limbux & 6.3 & 0 & 0.05 & 6.94 & 0.07 & 5.21 & 0.11 & 82 & 8.50 \\
\hline & Agri-56 & 6.0 & 0 & 0.03 & 4.87 & 0.11 & 5.10 & 0.11 & 77 & 10.11 \\
\hline & Filler & 4.6 & 59 & 0.03 & 0.97 & 0.31 & 3.35 & 0.11 & 70 & 10.93 \\
\hline \multirow[t]{3}{*}{16} & Limbux & 7.1 & 0 & 0.09 & 10.46 & 0.17 & 10.96 & 0.10 & 80 & 3.92 \\
\hline & Agri-56 & 6.5 & 0 & 0.03 & 10.41 & 0.14 & 10.73 & 0.11 & 60 & 9.50 \\
\hline & Filler & 5.0 & 28 & 0.03 & 1.78 & 0.43 & 3.22 & 0.10 & 69 & 12.88 \\
\hline
\end{tabular}

Table 5. Linear correlation coefficient ( $r$ ) between the different soil parameters and yield.

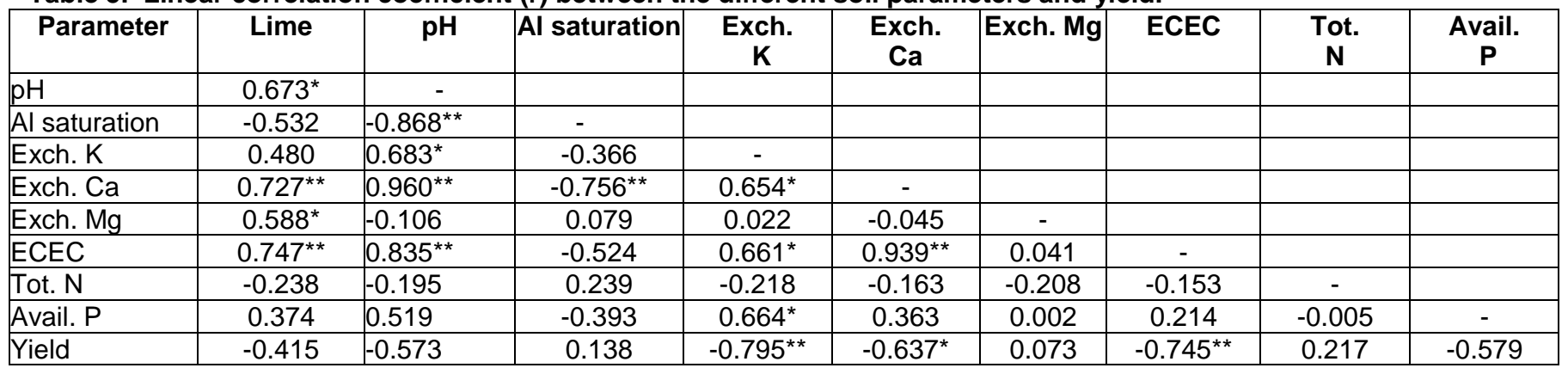

${ }^{* *}$ Correlation is significant at the 0.01 level (2-tailed)

${ }^{*}$ Correlation is significant at the 0.05 level (2-tailed). 


\section{CONCLUSIONS:}

The results of the present study showed that lime application rate at 2 tons ha $^{-1}$ gave an optimum dry matter yield. This indicates that liming at 2 tons ha ${ }^{-1}$ is required to ameliorate the acid condition of the experimental soil and over liming should be avoided as it could precipitate deficiency of the major nutrient elements. The local lime, "Agri-56" of CIMENCAMFiguil, was very efficient in neutralizing Al toxicity in the acid soil. Its performance is quite equivalent to that of the imported "Limbux". It should therefore be utilized in Cameroonian agriculture to achieve optimum agricultural production.

ACKNOWLEDGEMENTS: The authors are grateful to the "Cimenteries du Cameroun, CIMENCAM, for the funding of this study and to the staff of Ekona Agricultural Research Centre and the University of Buea for their invaluable assistance at different stages of this work.

\section{REFERENCES}

Adiloğlu, A and Adiloğlu, S (2004). An nvestigation on nutritional problems of hazelnut (Corylus avellana) grown in acid soils of Turkey. Pakistan J. Boil. Sci. 7: 1433-1437.

Amarasiri, S.L and Olsen, S.R (1973). Liming and related to solubility of phosphorus and plant growth in an acid tropical soil, Soil Sci. Soc.Am. Proc. 37: 716-721.

Anetor, M.O and Akinrinde, E.A (2006). Differences in the liming potential of some fertilizer materials in a tropical acid alfisol. J. Appl. Sci. 6: 1686-1691.

Black, C.A., Evans D.A., White J.L., Ensminger L.E and Clark F.E (1965). Methods of soil analysis Part 2. Am. Soc. Agron. Madison, Wisconsin, USA.

Bolan, W.S., Hedley, M.J and White R.E (1991). Processes of soil acidification during nitrogen cycling with emphasis on legume based pastures. In: Wright RJ, Baligar RJ, Murrmann VC (eds) Plant and soil interaction at low $\mathrm{pH}$. Phosphorus. Kluwer Academic Publisher, pp 159-167.

Conyers, M (1986). The relationship between average annual rainfall and exchangeable $\mathrm{Al}$ in soils of South Eastern New South Wales. Australian J. Exp. Agric. 26: 587-590.

De Miranda, L.N and Rowell, D.L (1987). The effects of lime and phosphorus on the function of wheat roots in acid topsoils and subsoils. Plant Soil 104: 253-262.

Evans, C.E and Kamprath, E.J (1970). Lime response as related to percent Al saturation, solution $\mathrm{Al}$ and organic matter content. Soil Sci. Soc. Am. Proc. 34: 893-896.

FAO/UNDP (1979). Soil Resources Project, Technical Report No. 2,

Fisher, J., Diggle A and Bowden, B (2003). Quantifying the acis balance for Broad-Acre Agricultural Systems, A.D. Robson (ed), Handbook of Soil Acidity. CRC Press, Boca Raton, Florida, pp 117-133.
Foth, H.D (1984). Fundamentals of soil science. John Wiley and Sons, Inc. New York, 435 pp.

Helyar, K.R and Porter, W.M (1989). Soil acidification, its measurement and the processes involved. In: Robson AD (ed) Soil Acidity and Plant Growth, Elsevier, New York, pp 61-101.

Keng, J.C.W and Uehara, G (1974). Chemistry, mineralogy and taxonomy of oxisols and ultisols. Proc. Soil Crop Sci. Soc. Florida 33: 119-126.

Kochian, L.V (1995). Cellular mechanisms of aluminium toxicity and resistance in plants. Annu. Rev. Plant Mol. Biol. Plant Physiol. 46:237-260.

Matsumoto, H (2000). Cell biology of aluminium toxicity and tolerance in higher plants. Int. Rev. Cytol. 200:1-46.

Nicholaides, J.J., Sanchez, P.A and Boul, S.W (1983). Proposal for the Oxisol-Ultisol Network of IBSRAM. Raleigh, North Carolina State University, 16 pp.

Oguntoyinbo, F.I., Aduayi, E.A and Sobulo, R.A (1996). Effectiveness of some local liming materials in Nigeria as ameliorant of soil acidity. J. Plant Nutr. 19: 999-1016.

Oluwayinbo, F.I., Akande, M.O and Adediran, J.A (2005). Response to okra (Abelmoschus esculentus) to lime and phosphorus fertilization in an acid soil. World J. Agric Sci. 1: 178-183.

Pearson, R.W (1975). Soil acidity and liming in the humid tropics, Cornell Int. Agric. Bull. 30.

Raij, B.V (1991). Fertility of acid soil. In : Wright RJ, Baligar RJ, Murrmann VC (eds) Plant and soil interaction at low pH. Phosphorus. Kluwer Academic Publisher, pp 159-167.

Sieffermann, G (1973). Sols de quelques régions du Cameroun: Variations pédologiques et minéralogiques du milieu équatorial au milieu tropical. Mémoires ORSTOM 66, Montpellier, France, $180 \mathrm{p}$.

Sanchez, P.A., Stoner, E.R and Pushparajah, E.D (1987). Management of acid tropical soils for sustainable agriculture. Proc. IBSRAM Inugural workshop. Bangkok Thailand, $107 \mathrm{pp}$.

Singh, L and Balasubramanian, V (1983). Crop responses to fertilizers, lime and micro-nutrients under continuous cultivation in northern Nigeria. Fert. Res. 4: 181-190

Soil Survey Staff (1994). Keys to Soil Taxonomy, $6^{\text {th }}$ Edn, US Dept of Agric.; Soil Conservation Service, Blacksburg, VA, USA, Pocahontas Press Inc.

Tchuenteu, F and Schalk, B (1988). Methods of the Ekona laboratory for soil, plant, water and fertilizer analysis. Part I: Routine methods for soil analysis, and Part II: Methods for plant analysis. FAO/UNDP Soil Resources Project Manual 3, Version 3.1. IRA Ekona, Cameroon.

Tening, A.S., Tchuenteu, F and Gwanpua, B.B (2008). Suitability of different extractants and turbidimetric reagents in the quantitative determination of sulphatesulphur in soils of South-western Cameroon. J. Cameroon Academy Sci. 7: 157-162. 